\title{
Strategy and Acceleration of Indonesia's Economic Growth against Policies during the Pandemic
}

\author{
Muhamad Arief Noor ${ }^{1}$, Pudji Astuty ${ }^{2}$ \\ \{ariefnoor319@gmail.com¹,puji_astuty@borobudur.ac.id ${ }^{1}$ \} \\ Universitas Borobudur, Jakarta, Indonesia ${ }^{1,2}$
}

\begin{abstract}
The economy in Indonesia during the COVID-19 pandemic has decreased compared to before the pandemic, although after a year and a half, our economy has gradually improved. Then what are the strategies and economic acceleration during the pandemic? This study used a descriptive qualitative method with a review of literature method. As per results of this study, the government must relax economic policies to improve people's purchasing power and increase fiscal and monetary policies to support the economy at the macro and micro levels. The research's conclusion is the government's policy scenario for managing with the economic downturn in two phases, utilizing a countercyclical approach, and in the new normal, using the acceleration of socio-economic recovery to reduce economic impact of the pandemic.
\end{abstract}

Keywords: Strategy; Acceleration Economics; Policy of Economic

\section{Introduction}

The Covid-19 pandemic is an extraordinary health problem that has hit the whole world, including Indonesia.[1] The swift and widespread spread of Covid-19 across countries impacts all aspects of human life in various fields, including the economy. Most countries in the world have entered a phase of economic recession because of the impacts of the Covid-19 pandemic, both developed and developing countries.[2] A recession is a condition of economic growth in two consecutive quarters experiencing negative growth or a decline in Gross Domestic Product (GDP) that occurred for two straight quarters. A recession occurs because of a significant decrease in economic activity that lasts for several months or even years, which is caused by the effect of the Covid-19 pandemic.[3]

Suppose the recession does not get severe and responsive handling from the government. In that case, it will undoubtedly impact slowing economic growth and a multiplier effect on all economic activities in the long term. An unanticipated recession through the government's policy scenario can cause the country's economy to enter a depression phase, which takes a long time and a large budget to restore the country's collapsing economic condition.[4]

The global economy is forecasted for higher growth with a likely uneven recovery. The global monetary recuperation will be supported by the recovery in the US and China.[3] Meanwhile, recovery in other countries tends to be more moderate. Global economic growth 
and world trade are improving but at different rates. The volume of world trade continues to show an increase. Global retail sales improved, especially in the US.

Some of the growth acceleration strategies that the government has launched for 2021 include the preparation of the Investment Priority List (DPI), the establishment of an Investment Management Agency, economic policies that favor small and medium-sized businesses, a vaccine program, and the existence of the Job Creation Act. as a form of simplification of financial regulation.[5]

The Covid-19 pandemic has caused Indonesia to experience its worst economic downturn in 20 years. The second and third-quarter economic growth in 2020 was $-5.32 \%$ and $-3.49 \%$, respectively. Poverty and unemployment rates have also increased sharply. Indonesia is facing a pandemic resurgence as a result of the long holiday. The difference with EU countries, Indonesia, with its relatively high level of informality, requires policies designed by taking into account the expectations of the formal and informal sectors.

\section{Methods}

This research is a descriptive qualitative study to examine economic policies during the COVID-19 pandemic. The author uses an analytical approach with a literature study to answer some of the research questions in this paper.[6] The study materials that the author uses are several articles indexed by Scopus and the Web of Science to get a research reputation recognized by the scientific world. [7]

\section{Discussion}

Various policies could be used to stimulate economic growth recover during the COVID19 pandemic, spanning from leisure to the restoration of national food production agriculture so that we do not run out of food and imports are minimized.[8] The second quarter illustrates that the direction of economic recovery is correct, the economic recovery strategy is also proper, and has started to produce impacts or results. This economic recovery can be seen from all the growth engines, which are now beginning to recover. Household consumption grew by $5.9 \%$, and investment grew at $7.5 \%$, trade grew at $9.4 \%$, the construction sector grew $4.4 \%$, transportation at $25.1 \%$, and food and beverage accommodation by $21.6 \%$.

The manufacturing sector, which contributes to nearly $20 \%$ of Gross Domestic Product (GDP), also grew 6.6\%. Export performance since the first quarter has started to enter the positive zone of $7 \%$, and the second quarter has increased to $31.8 \%$. Likewise, imports grew $5.5 \%$ in the first quarter, and the momentum accelerated and strengthened in the second quarter at $31.2 \%$.

Today's society has entered the time of the information society, that is connected to the virtual world. This occurrence has occurred not only in metropolitan areas, but also in rural areas. Information and communication technology has advanced to the point where it can currently support many parts of human activity, including agriculture and agricultural extension. One approach for meeting these demands is to promote advanced, personality, and modern agriculture. Human resource capability and increased technological adoption are critical components of achieving these objectives. The deployment of information technology could be one way to do this. As according research done in a variety of nations, 
Indonesia's economic growth in Q-1 grew by $3 \%$, but in Q2, it contracted by $-5.3 \%$. Economic growth in Q-2 2020 contracted due to the impact of strict restriction policies to forestall the spread of the Covid-19 pandemic. Restrictions on activities that have been carried out have stopped the community's economic activities and hampered the production and distribution of goods. Economic activities are restricted to domestic activities and foreignrelated economic activities (exports and imports). This causes a decline in financial performance as indicated by a slowdown in economic growth or even a weakening (contraction) economy. The decline in economic performance that is not responded to through policies by the government quickly and carefully will result in the country's economy experienced an economic recession, even an economic depression. The term recession in conjuncture economic theory is a decline in economic activity that occurs above-normal growth. From the macroeconomic aspect, a recession means a period in which the Gross Domestic Product (GDP) decays when genuine financial development is negative.

A recession can cause a simultaneous decline in every financial action, like business, speculation, and corporate benefits. Qualitatively, this follows the law of demand (demand side), which relates to the cessation of order from the consumer side due to social restrictions (lockdown policies), thereby reducing all economic activity. Meanwhile, there was a slowdown in production from the supply side because the supply of raw materials was hampered due to the regional quarantine. This causes an imbalance between supply and demand, thus disrupting the market equilibrium for economic growth.

According to Schumpeter, the concept of the economic cycle in the growth and recession model has two phases in the model, namely: above and below. When systems and regulations are adjusted to high consumer confidence, the economy will experience an upswing phase. On the other hand, an economic recession becomes unavoidable when the line leads down to below the inflection point when times are tough. The equilibrium line shows the initial period and measures economic growth and decline (contraction). The government as a regulator will have difficulty creating a positive climate to stimulate economic growth activity in the community. When conditions worsen, the economic depression becomes more open or described as a country's financial failure or economic bankruptcy.

The COVID-19 pandemic has created uncertainty in the direction of economic growth, both globally and domestically. This uncertainty carries a very high risk. However, if responsive and careful policies are not taken, it will impact a recession or enter a phase of economic depression. Therefore, responsive policies and extraordinary measures are needed to mitigate the distorting impact on health, social and economic aspects. According to the business cycle theory, macroeconomic policy options that can be taken to overcome financial instability in the recession phase are procyclical policies and countercyclical policies. The procyclical policy is a policy that follows the flow of the business cycle, meaning that during a recession, the government implements contractionary procedures in the form of fiscal and monetary tightening. Meanwhile, countercyclical policies go against the flow of the business cycle. Namely, during a recession, the government implements expansionary procedures in fiscal and monetary easing.

The Indonesian economy experienced high tension during 2020 because of the Covid-19 pandemic, which was demonstrated by the decrease in state incomes to Rp 1,666.9 trillion; expansion in state spending by Rp 2,739.2 trillion; an increment in the state deficiency by $6.34 \%$ (surpassing the $3 \%$ furthest reaches of GDP); and expanded obligation financing by Rp $1,039.2$ trillion. In light of BPS information (2020), the modified consequence of Bank Indonesia predicts that Indonesia's financial development in 2020 will be $4.2 \%-4.6 \%$, which is higher than the appraisals from the ADB (2.5\%) and the IMF $(0.5 \%)$. This is because of the 
strategy of restricting the versatility of local area exercises, including creation exercises and other monetary exercises, which causes a decrease in monetary execution. The public authority has taken countercyclical strategy situations to keep up with financial strength that is encountering constriction for monetary recuperation during the Covid-19 pandemic. The Government of Indonesia has given an arrangement as expressed in Government Regulation Number 23 of 2020 concerning Implementation of the National Economic Recovery Program to Support State Financial Policies for Handling the Corona Virus Disease 2019 (Covid-19) Pandemic and Facing Threats That Endanger the National Economy and System Stability Finance and Saving the National Economy.

This strategy is a development toward the Government Protections in Place of Law Number 1 of 2020 Concerning State Financial Policy and Financial Stability Of the framework for Having to deal with the Corona Pandemic in Economic Rehab Programs to Save the National Economy, which is a development to the Government Law in Place of Law Number 1 of 2020 Concerning State Financial Policy and Financial System Stability for Having to deal with the Corona Pandemic in Economic Addiction Treatment to Save the National Economy. In respects of bureaucratic monetary recuperation, the public authority's approach situation is similarly as follows: First, there was the issue of state value interest. PMN is the method of parting state resources from APBN or setting up organization saves or different wellsprings of money to be utilized as capital for State-Owned Enterprises (BUMN) and other restricted responsibility organizations which are overseen corporately. PMN is being created to build the capital construction of State endeavors and State - possessed venture auxiliaries impacted by the Covid-19 pandemic, and to expand the business limit of BUMN and BUMN auxiliaries, and to complete government supported tasks in the execution of public financial recuperation. The public authority can lead PMN to SOEs or through chose SOEs as a feature of its presentation. Second, Fund Placement is an administration activity where cash are put in explicit business foundations with a particular premium. The finances will be utilized to give liquidity to banks that are rebuilding their credit (financing) and giving extra credit (financing) for working capital Funds are disseminated to Participating Banks that meet the accompanying necessities: a) Commercial keeps money with Indonesian lawful elements working in Indonesian region, with Indonesian residents or Indonesian legitimate elements claiming something like $51 \%$ of the offers; b) a bank in the solid class dependent on the OJK's appraisal of the bank's sufficiency; and c) a bank in the classification of the 15 biggest banks by resources. Third, government venture is the drawn out arrangement of different accounts and monetary resources for interest in shares, obligation protections, and direct interest to procure financial, social, and different advantages - executing government interest as per appropriate enactment. .Fourth, ensuring is the activity of giving certifications by conveying assets to Participating Banks that meet the accompanying standards.: a) Commercial manages an account with Indonesian legitimate substances working in Indonesian region, with somewhere around $51 \%$ of the offers possessed by Indonesian residents or Indonesian lawful elements; b) a bank that is delegated solid dependent on the OJK's evaluation of its sufficiency; and c) a bank that positions among the best 15 banks as far as resources. Ensured monetary commitments to the assurance recipient should be met by the underwriter. Certifications can be given straight by the public authority or through an assigned Business Entity. PT. Indonesian Credit Guarantee and PT. Indonesian Credit Insurance have been named as the named business elements.

The government can fund its implementation by issuing Government Securities (SBN), which will be purchased on the primary market by Bank Indonesia. The proceeds from the issuance of SBN are kept in a particular account at Bank Indonesia. The public monetary 
recuperation strategy is important for the state monetary (financial) approach carried out by the public authority to speed up the treatment of the Covid-19 pandemic and manage dangers that jeopardize the public economy and monetary framework dependability to drive public financial growth in the third quarter. Carry out national economic recovery using a countercyclical approach. Countercyclical policies stabilize the business cycle because fiscal is contractionary during expansion and expansionary when contraction occurs. Policies with a countercyclical character have the potential to shorten the recession phase and accelerate the recovery process.

In the absence of drugs to deal with the Covid-19 pandemic, the government must make extraordinary efforts, including a policy of restricting the mobility of people and goods. These efforts have an impact on the Indonesian economy, resulting in a contraction. This is due to the high level of uncertainty so that it becomes a disincentive for business actors to invest. This condition causes an increase in the number of unemployed and impacts business sustainability, exceptionally indirectly affected sectors. The Covid-19 pandemic has been heavily pressured, both on the supply and demand side. This creates a vicious circle that has a direct impact on the level of community welfare.

Due to the limitation of human mobility, some business actors have to reduce their operational costs because their income has decreased significantly, where one option is to do layoffs. This impacts increasing the number of unemployed and reducing people's income, causing a decrease in people's purchasing power and increasing the number of poor people, then growing social inequality. These changes impact the community's quality of life, thus affecting the decline in the Human Development Index.

In reaction to the Covid-19 pandemic, the government has implemented a policy in the form of a countercyclical approach in Law 2/2020 to accelerate Covid-19 reaction and socioeconomic recovery. The availability of medicines and vaccinations is a step and pattern of healing, and it is supposed to start in 2021. During the new normal, the stimulus policy for national improving economy is expected to create a rebound, boosting welfare indicators.[9] The going with is the public authority's approach situation for the public economy's recuperation during the new ordinary in the macroeconomic structure: First, the strategy has been executed by speeding up the mending of the corporate world affected by Covid-19 pandemic though the procedure to manage wellbeing recuperation and social security impacts - Coronavirus pandemic. Second, expanding monetary seriousness by empowering more noteworthy limit with respect to improvement and advanced transformation. Third, segment conditions are a strategy to work on transient monetary turn of events and further develop business openings. Fourth, keep changes going to guarantee the drawn out feasibility of primary upgrades that help medium-and long haul financial development. Fifth, monetary change intends to hurry the assembling business' change and urge Indonesian makers to create cutting edge items. At long last, escape the working class groove. The disappointment of a nation to update from lower-center pay to upper-center pay is known as the center pay trap. Indonesia will logically break liberated from the center pay trap by expanding usefulness, seriousness, and human asset quality. (particularly work).[10] Redirect some utilization spending to help useful sorts of expenditure. Exploration results Aghion et al. (2007) show that the modern area is developing quickly (yield and efficiency levels) in an economy with a countercyclical monetary.

\section{Conclusion}


The policies taken by the government to recover the national economy are aimed at increasing the prevention of the spread of the epidemic, helping the affected community and business world not to collapse so that when the Covid-19 pandemic passes, they can rise from the economic downturn. The policy scenarios taken by the government can be categorized into two phases of economic recovery using a countercyclical approach, namely: the Covid-19 pandemic period and the new standard period. During the Covid-19 pandemic, the policy is intended to maintain economic stability, experiencing stagnation and contraction. Meanwhile, the policy scenario accelerates socio-economic recovery in the latest average period and creates a rebound to improve welfare indicators.

The government's various policy scenarios in multiple countries (including Indonesia) do not avoid a recession because a recession that hit during the Covid-19 pandemic with an unpredictable period is necessary. However, the economy remained contracted for two consecutive quarters. The government has made many efforts to restore the national economy. Still, a recession should not measure these efforts. If a downturn occurs, it does not mean that the optimal efforts made by the government are called failed and useless, but extraordinary conditions that are unpredictable and uncertain. From the point of view of economic growth (in the short term), the economy is not one of the determinants of welfare. However, in current conditions, human life and health have a higher economic value because if they do not receive proper treatment, they can cause more significant financial losses in the long term when the Covid-19 pandemic ends.

\section{References}

[1] F. Santiago, "Credit Relaxation Policy During Covid-19 Reviewed from the Force Majeure Aspect," 2021, doi: 10.4108/eai.6-3-2021.2306389.

[2] R. Listio and F. Santiago, "Analysis of the Role of Insurance Law of the Impact of the Covid-19 Pandemic for Indonesian Community Insurance," 2021, doi: 10.4108/eai.6-32021.2306294.

[3] T. N. Mursitama and Y. Ying, "Indonesia's Perception and Strategy toward China's OBOR Expansion: Hedging with Balancing," Chinese Econ., vol. 54, no. 1, pp. 35-47, 2021, doi: 10.1080/10971475.2020.1809816.

[4] BKPM, Perkembangan Realisasi Investasi 2015 - Maret 2020: Per Triwulan, no. Januari. 2021, pp. 1-5.

[5] E. E. Supriyanto, "Strategi Penerapan Kebijakan Sovereign Wealth Funds (SWFs) di Indonesia: Studi Literatur dan Studi Komparatif Oman,” J. Inov. Ilmu Sos. dan Polit., vol. 3, no. 1, p. 10, Apr. 2021, doi: 10.33474/jisop.v3i1.6959.

[6] S. Houghton-Jan, A. Etches-Johnson, and A. Schmidt, "The read/write web and the future of library research," J. Libr. Adm., vol. 49, no. 4, pp. 365-382, 2009, doi: 10.1080/01930820902832496.

[7] M. Fallon, Writing up quantitative research in the social and behavioral sciences. Brill Sense, 2016.

[8] E. E. Supriyanto, "Politik Kebijakan Ketahanan Pangan Indonesia Pasca Pandemi Covid-19," in Pertanian Dalam Ketahanan Pangan Selama dan Sesudah Covid-19, vol. 1, no. 1, Denpasar: Penerbit Yayasan Guna Widya Paramesthi, 2021, pp. 33-43.

[9] D. Kurniawan, A. Sutan, I. Mufandi, E. Supriyanto, and M. Rachmawati, "Social Media Used to Spread Vaccination Program: Case of Indonesia Vaccination Covid-19 Policy,” 2021, doi: 10.4108/eai.6-3-2021.2306469. 
[10] E. E. Supriyanto, Eksistensi Nilai-Nilai Pancasila Dalam Kebijakan Ekonomi Indonesia, 1st ed., no. September. Malang: Literasi Nusantara, 2020. 